\title{
Innovative Modified of Cu-Al/C (C = Biochar, Graphite) Composites for Removal of Procion Red from Aqueous Solution
}

\author{
Alfan Wijaya', Patimah Mega Syah Bahar Nur Siregar², Aldi Priambodo', Neza Rahayu Palapa ${ }^{1,3}$, Tarmizi Taher ${ }^{4}$, Aldes Lesbani1 ${ }^{1,3 *}$ \\ ${ }^{1}$ Research Center of Inorganic Materials and Complexes, Faculty of Mathematics and Natural Sciences, Universitas Sriwijaya, Palembang, 30139, Indonesia \\ ${ }^{2}$ Magister Programme Graduate School of Mathematics and Natural Sciences, Universitas Sriwijaya, Palembang, 30139, Indonesia \\ ${ }^{3}$ Graduate School, Faculty of Mathematics and Natural Sciences, Universitas Sriwijaya, Palembang, 30139, Indonesia \\ ${ }^{4}$ Department of Environmental Engineering, Institut Teknologi Sumatera, Lampung Selatan, 35365, Indonesia \\ *Corresponding author: aldeslesbani@pps.unsri.ac.id
}

\begin{abstract}
Innovative modification of $\mathrm{Cu}-\mathrm{Al} / \mathrm{C}$ composites was synthesized by coprecipitation method at $\mathrm{pH} 10$ and added biochar (BC) and graphite (GF) to form Cu-Al/BC and Cu-Al/GF composites. Pristine and composites were characterized by XRD, FT-IR, Thermalgravimetric, and surface area using the BET method. The XRD diffraction and FTIR spectrum of Cu-Al/BC and Cu-Al/GF showed that the composite material from LDH, biochar, and graphite was successfully prepared. Modified LDH were surface area higher than the pristine, which obtained $200.90 \mathrm{~m}^{2} / \mathrm{g}$ and $18.83 \mathrm{~m}^{2} / \mathrm{g}$ for $\mathrm{Cu}-\mathrm{Al} / \mathrm{BC}$ and $\mathrm{Cu}-\mathrm{Al} / \mathrm{GF}$ respectively. Cu-Al/BC and Cu-Al/GF were tested for selectivity on several anionic dyes, it was known that procion red (PR) dye was more easily adsorbed than other anionic dyes. Materials were applied as adsorbents of procion red (PR) dye. The advantages of composites were evaluated by the regeneration process of adsorbent on PR. The result of composite toward PR re-adsorption process showed that Cu-Al/BC and Cu-Al/GF had structural stability higher than starting materials until five cycles process. Furthermore, materials were applied as adsorbents of procion red (PR) dye. The maximum adsorption capacity obtained was $93.458 \mathrm{mg} / \mathrm{g}$ for Cu-Al/BC and $49.505 \mathrm{mg} / \mathrm{g}$ for Cu-Al/GF. Both innovative modified composites have shown effective adsorbents to the removal of PR from an aqueous solution.
\end{abstract}

Keywords

Composites, Adsorption, Procion Red Dye, Selectivity, Structural Stability

Received: 27 April 2021, Accepted: 17 July 2021

https://doi.org/10.26554/sti.2021.6.4.228-234

\section{INTRODUCTION}

Synthetic dyes have become widely used due to their being more durable, more colorful, low cost, and easy to apply on domestic and industrial scales (Lellis et al., 2019). The increasing use of synthetic dyes can create several disadvantages not only for the environment but also for human health. The wastewater of synthetic dyes is an organic pollutant that is difficult to degrade by nature (Eltaweil et al., 2020). One of the synthetic dyes that are intensively used in industrial applications is procion red (PR) (Hua et al., 2020). The structure of PR is shown in Figure 1.

Toxicity of PR thus removal of PR was vital. Various methods to remove dyes wastewater such as photocatalytic degradation (Kumar and Rao, 2017; Natarajan et al., 2020), biological treatment (Tang et al., 2020; Sarkar et al., 2017), coagulation (Mcyotto et al., 2021; Demissie et al., 2021), and adsorption (Palapa et al., 2018; Palapa et al., 2020a; Siregar et al., 2021) have been tested. Adsorption is a method that is widely used



Figure 1. Chemical Structure of Procion Red (PR)

to remove dyes due more efficient, fast process, and cheap (Eltaweil et al., 2020). Many adsorbents can be used to absorb dyes such as kaolin (Mustapha et al., 2019), activated carbon (Quesada et al., 2020; Streit et al., 2019), bentonite (Mohammad et al., 2020), chitosan (Shi et al., 2020), and LDH (layered double hydroxide) (Palapa et al., 2019; Zhao et al., 2017; Palapa et al., 2020b; Siregar et al., 2021; Normah et al., 2021; Juleanti et al., 2021). Layered double hydroxide (LDH) 
has high ion exchange and adsorption ability making LDH an appropriate adsorbent for adsorption of various pollutants. $\mathrm{LDH}$ has a granular structure and a less stable structure. These properties make the limitation of LDH an adsorbent, especially for the reusability process.

Research conducted by Palapa et al. (2018) using Ni/Al and $\mathrm{Zn} / \mathrm{Al} \mathrm{LDH}$ s to adsorb direct yellow dye showed the efficient process of adsorption. $\mathrm{Cu} / \mathrm{Al} \mathrm{LDH}$ was applied to adsorb malachite green dye with also efficient results (Palapa et al., 2020b). Zn/Fe and $\mathrm{Zn} / \mathrm{Al}$ were used as efficient adsorbents to adsorb direct yellow dye (Palapa et al., 2019), and $\mathrm{Mg} / \mathrm{Al}$ LDH to adsorb methylene blue dye (Zhao et al., 2017). All results showed that $\mathrm{LDH}$ has a limitation as adsorbent for reuse process, thus modification of LDH is needed to enhance the ability of LDH for dyes adsorption. By modification of LDH through impregnation by carbon-based materials can create the structure stability and performance of LDH. One of the potential carbon materials for $\mathrm{LDH}$ support is biochar $(\mathrm{BC})$ and graphite (GF).

Composite of $\mathrm{Cu}-\mathrm{Al} / \mathrm{BC}$ was prepared as adsorbent of malachite green produce an adsorption capacity of 108.96 $\mathrm{mg} / \mathrm{L}$ (Palapa et al., 2020b). Mg/Al-BC composite was also successfully used as an adsorbent of malachite green with an adsorption capacity of $70.922 \mathrm{mg} / \mathrm{g}$ (Badri et al., 2021) and $\mathrm{Mg} / \mathrm{Al}-\mathrm{Carbon}$ Dot composite was synthesized to adsorb methylene blue with an adsorption capacity of $185 \mathrm{mg} / \mathrm{g}$ (Zhang et al., 2014). In this research, $\mathrm{Cu}-\mathrm{Al} / \mathrm{BC}$ and $\mathrm{Cu}-\mathrm{Al} / \mathrm{GF}$ composites are prepared, used as adsorbents, and tested for selectivity on several anionic dyes to know which dyes are more easily adsorbed. The adsorption parameters to be studied in this study include adsorption isotherms and adsorption thermodynamics which are calculated using the Langmuir and Freundlich equation. The stability of composites is evaluated by regeneration of adsorbent until five cycles adsorption process.

\section{EXPERIMENTAL SECTION}

\subsection{Chemicals and Instrumentation}

The chemicals used in the experiment were $\mathrm{Cu}\left(\mathrm{NO}_{3}\right)_{2} \cdot 3 \mathrm{H}_{2} \mathrm{O}$ by EMSURE巴 ACS, $\mathrm{Al}\left(\mathrm{NO}_{3}\right)_{3} .9 \mathrm{H}_{2} \mathrm{O}$ by Sigma Aldrich, $\mathrm{NaOH}$ by EMSURE® ACS, rice husk was obtained from Bukata Organic ${ }^{\circledR}$, Indonesia, fabricant graphite from Sigma Aldrich and water was demineralized using Purite ${ }^{\circledR}$ water purification apparatus. Pristine and composites were characterized by XRD, FTIR, and BET. Analysis XRD was performed by Rigaku Miniflex-6000 diffractometer. FT-IR characterization using FT-IR Shimadzu Prestige-21. Analysis BET using Quantachrome Micrometic ASAP. The concentration of PR was analyzed using Spectrophotometer Ultra Violet-Visible Biobase BK-UV $1800 \mathrm{PC}$ at a wavelength of $545 \mathrm{~nm}$.

\subsection{Preparation of $\mathrm{Cu} / \mathrm{Al} \mathrm{LDH}$}

Synthesis of $\mathrm{Cu} / \mathrm{Al} \mathrm{LDH}$ was conducted as a similar procedure by Palapa et al. (2020b) using the coprecipitation method at $\mathrm{pH}$ 10. The synthesis of $\mathrm{Cu} / \mathrm{Al} \mathrm{LDH}$ was carried out in the following procedure: as much as $100 \mathrm{~mL}$ of $\mathrm{Cu}\left(\mathrm{NO}_{3}\right)_{2} .3 \mathrm{H}_{2} \mathrm{O}$
$0.75 \mathrm{M}$ was mixed with $100 \mathrm{~mL} \mathrm{Al}\left(\mathrm{NO}_{3}\right)_{3} .9 \mathrm{H}_{2} \mathrm{O} 0.25 \mathrm{M}$ (3:1) in a beaker. The reaction was stirred until homogeneous mixtures then $50 \mathrm{~mL} \mathrm{NaOH} 2 \mathrm{M}$ was added until $\mathrm{pH} 10$. The mixture was stirred for 20 hours. The solid precipitate was then filtered, washed and dried at $110^{\circ} \mathrm{C}$ for 120 minutes.

\subsection{Preparation of $\mathrm{Cu}-\mathrm{Al} / \mathrm{BC}$ and $\mathrm{Cu}-\mathrm{Al} / \mathrm{GF}$}

$\mathrm{Cu}-\mathrm{Al} / \mathrm{BC}$ and $\mathrm{Cu}-\mathrm{Al} / \mathrm{GF}$ Composites were prepared using the coprecipitation method in the following procedure: as much as $10 \mathrm{~mL} \mathrm{Cu}\left(\mathrm{NO}_{3}\right)_{2} .3 \mathrm{H}_{2} \mathrm{O} 0.75 \mathrm{M}$ mixed with $10 \mathrm{~mL}$ $\mathrm{Al}\left(\mathrm{NO}_{3}\right)_{3} .9 \mathrm{H}_{2} \mathrm{O} 0.25 \mathrm{M}$ and stirred for 60 minutes until homogeneous. The resulting mixture was added with $1 \mathrm{~g}$ of $(\mathrm{BC}$ or GF) while stirring and added with $\mathrm{NaOH} 2 \mathrm{M}$ until pH 10 . The mixed solution was stirred for 3 days at a temperature of $80{ }^{\circ} \mathrm{C}$. The composites were filtered, washed and dried at 40 ${ }^{\circ} \mathrm{C}$ for 120 minutes.

\subsection{Selectivity of Anionic Dye Mixtures}

The selectivity of anionic dye mixtures was carried out to find the most widely absorbed anionic dyes in each adsorbent by mixing anionic dyes of congo red (CR), procion red (PR), methyl orange (MO) and methyl red (MR) with the same concentration, then added adsorbents and stirred with a time variation of $15,30,60,90$, and 120 minutes, then measured absorbance at the wavelength of each dye.

\subsection{Desorption and Regeneration of Adsorbent}

The desorption process was carried out to test the adsorbent efficiency for the reuse of the adsorbent. In this study, the desorption process was used as an ultrasonic process. The desorption process was carried out using $50 \mathrm{~mL}$ of PR. As much as $50 \mathrm{mg} / \mathrm{L}$ was added with $1 \mathrm{~g}$ of adsorbent and stirred for 120 minutes. Then, dry the used adsorbent and take $0.01 \mathrm{~g}$, add $10 \mathrm{~mL}$ of water to the ultrasonic process. The regeneration process using the adsorbent that has been used is as follows: $50 \mathrm{~mL}$ of $\mathrm{PR}$ at $50 \mathrm{mg} / \mathrm{L}$ was stirred for 120 minutes and solution was measured using a UV-Vis Spectrophotometer at $545 \mathrm{~nm}$. The dried adsorbent was then used again for the desorption process, successively. The adsorbent was applied until five cycles adsorption process with the same procedure as the initial run.

\subsection{Adsorption Process}

The adsorption process of PR was studied through the influence of the initial concentration of PR and adsorption temperature. The variation of initial concentration of $\mathrm{PR}$ and temperature adsorption was carried out with the concentration of CR (60, $70,80,90$ and 100) $\mathrm{mg} / \mathrm{L}, 0.02 \mathrm{~g}$ of adsorbent and $20 \mathrm{~mL}$ of PR, then stirred for 100 minutes with a variation of the adsorption temperature at $30,40,50$, and $60^{\circ} \mathrm{C}$. The concentration of the PR was measured by UV-Vis spectrophotometer at $545 \mathrm{~nm}$. Thermodynamic parameters were obtained from the Langmuir and Freundlich equations. Langmuir is assumed to be a chemical and monolayer adsorption process, while Freundlich is assumed to be a physical and multilayer adsorption 
process. Isotherm Langmuir and Freundlich's equations are according to previous works of literature (Palapa et al., 2020b).

\section{RESULTS AND DISCUSSION}

Diffractogram of $\mathrm{Cu} / \mathrm{Al} \mathrm{LDH}, \mathrm{BC}, \mathrm{GF}$ and composites are shown in Figure 2. $\mathrm{Cu} / \mathrm{Al} \mathrm{LDH}$ materials have typical peaks with good crystallinity with diffraction angles at $11.6^{\circ}(003)$, $23.5^{\circ}(006), 34.3^{\circ}(101), 35.1^{\circ}(012), 37.8^{\circ}(104), 39.8^{\circ}(015)$, $44.4^{\circ}(107), 47.3^{\circ}(018)$ and $61.4^{\circ}(110 / 113)$ indicated that the formation of the $\mathrm{Cu} / \mathrm{Al} \mathrm{LDH}$ structure was following the JCPDS 46-0099 file. Figure 2b showed that broad peak the presence of high carbon content on $\mathrm{BC}$ with diffraction at $22.30^{\circ}(002)$. The diffraction patterns of GF as shown in Figure $2 \mathrm{c}$, material has good crystallinity with diffraction at $26.4^{\circ}$ (002). The diffraction patterns of $\mathrm{Cu}-\mathrm{Al} / \mathrm{BC}$ as shown in Figure $2 \mathrm{~d}$ resemble the diffraction patterns of $\mathrm{Cu} / \mathrm{Al} \mathrm{LDH}$ and biochar. The $\mathrm{Cu}-\mathrm{Al} / \mathrm{BC}$ composite material has an amorphous diffraction pattern due to the characteristics of biochar with a diffraction peak of around $23^{\circ}$. The diffraction pattern in $\mathrm{Cu}-\mathrm{Al} / \mathrm{GF}$ as shown in Figure 2e resemble that of $\mathrm{Cu} / \mathrm{Al} \mathrm{LDH}$ and graphite. $\mathrm{Cu}-\mathrm{Al} / \mathrm{GF}$ composite material is shown in Figure $2 \mathrm{e}$ which shows that there are typical peaks of $\mathrm{Cu} / \mathrm{Al} \mathrm{LDH}$ and graphite. According to Kusrini et al. (2019) Cu-Al/GF composite material has a distinctive diffraction pattern of graphite around $26.54^{\circ}(002)$ with sharp peaks.

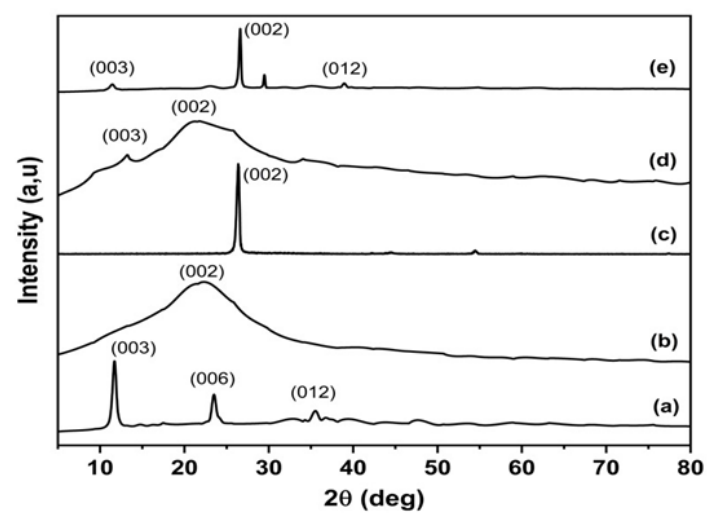

Figure 2. XRD Powder Patterns of Cu/Al LDH (a), BC (b), GF (c), $\mathrm{Cu}-\mathrm{Al} / \mathrm{BC}$ (d), and $\mathrm{Cu}-\mathrm{Al} / \mathrm{GF}$ (e)

Nitrogen adsorption-desorption analysis on $\mathrm{Cu} / \mathrm{Al} \mathrm{LDH}$, $\mathrm{BC}, \mathrm{GF}$ and $\mathrm{Cu}-\mathrm{Al} / \mathrm{BC}$ and $\mathrm{Cu}-\mathrm{Al} / \mathrm{GF}$ composites is shown in Figure 3. Figure 3 shows that the nitrogen adsorption pathway is not the same as the nitrogen desorption pathway which indicates that the material has hysteresis. The hysteresis that occurs in the graph shows the pores in the material. The pattern in Figure 3 shows that the materials in $\mathrm{Cu} / \mathrm{Al} \mathrm{LDH}, \mathrm{BC}, \mathrm{GF}, \mathrm{Cu}-$ $\mathrm{Al} / \mathrm{BC}$ and $\mathrm{Cu}-\mathrm{Al} / \mathrm{GF}$ composites follow type IV isotherms. Type IV isotherm shows hysteresis of mesoporous sized materials with strong hysteresis activity on the adsorbent-adsorbate interaction.

Table 1 showed that $\mathrm{Cu}-\mathrm{Al} / \mathrm{BC}$ had surface area four-fold than pristine $\mathrm{LDH}$ and $\mathrm{BC}$. The results of the BET analysis

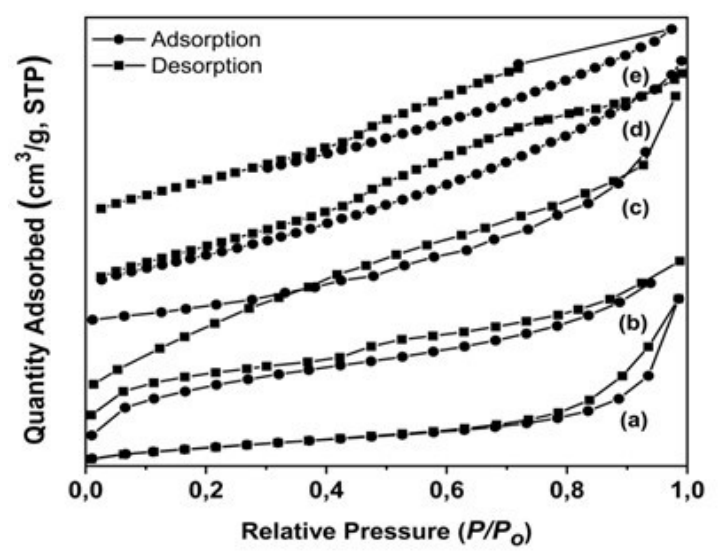

Figure 3. BET profile of $\mathrm{Cu}-\mathrm{Al} \mathrm{LDH}(\mathrm{a}), \mathrm{BC}(\mathrm{b}), \mathrm{GF}(\mathrm{c})$, $\mathrm{Cu}-\mathrm{Al} / \mathrm{BC}(\mathrm{d})$, and $\mathrm{Cu}-\mathrm{Al} / \mathrm{GF}(\mathrm{e})$

showed that the starting material had an increase in surface area after the formation of composites which obtained 200.90 and $18.83 \mathrm{~m}^{2} / \mathrm{g}$ for $\mathrm{Cu}-\mathrm{Al} / \mathrm{BC}$ and $\mathrm{Cu}-\mathrm{Al} / \mathrm{GF}$ respectively. This shows that the synthesis process has been successful.

Table 1. BET Analysis of Materials

\begin{tabular}{cccc}
\hline Materials & $\begin{array}{c}\text { Surface Area } \\
\left(\mathrm{m}^{2} / \mathrm{g}\right)\end{array}$ & $\begin{array}{c}\text { Pore Size } \\
(\mathrm{nm}), \mathrm{BJH}\end{array}$ & $\begin{array}{c}\text { Pore Volume } \\
\left(\mathrm{cm}^{2} / \mathrm{g}\right), \mathrm{BJH}\end{array}$ \\
\hline $\mathrm{Cu}-\mathrm{Al} \mathrm{LDH}$ & 46.279 & 10.393 & 0.116 \\
$\mathrm{BC}$ & 50.936 & 12.089 & 0,025 \\
$\mathrm{GF}$ & 9.394 & 3.169 & 0.027 \\
$\mathrm{Cu}-\mathrm{Al} / \mathrm{BC}$ & 200.90 & 7.03 & 0.350 \\
$\mathrm{Cu}-\mathrm{Al} / \mathrm{GF}$ & 18.83 & 3.132 & 0.046 \\
\hline
\end{tabular}

Figure 4a shows the FTIR spectrum of $\mathrm{Cu} / \mathrm{Al} \mathrm{LDH}$ had vibrations at $3448 \mathrm{~cm}^{-1}$ which indicates the presence of $\mathrm{O}$ $\mathrm{H}$ stretching, $1635 \mathrm{~cm}^{-1}$ presence of $\mathrm{O}-\mathrm{H}$ bending, 1381 $\mathrm{cm}^{-1}$ presence of $\mathrm{N}-\mathrm{O}$ stretching, $794 \mathrm{~cm}^{-1}$ presence of Al$\mathrm{O}$ and $462 \mathrm{~cm}^{-1}$ presence of $\mathrm{Zn}-\mathrm{O}$ and $\mathrm{Cu}-\mathrm{O}$. The FTIR spectrum of $\mathrm{BC}$ and $\mathrm{Cu}-\mathrm{Al} / \mathrm{BC}$ as shown in Figures $4 \mathrm{~b}$ and $4 \mathrm{~d}$ had vibrations that indicate the presence of $\mathrm{O}-\mathrm{H}$ stretching, C-H bending, $\mathrm{O}-\mathrm{H}$ bending, and $\mathrm{C}-\mathrm{O}$ stretching. The FTIR spectrum of $\mathrm{GF}$ and $\mathrm{Cu}-\mathrm{Al} / \mathrm{GF}$ as shown in Figures $4 \mathrm{c}$ and $4 \mathrm{e}$ had vibrations presence of $\mathrm{O}-\mathrm{H}$ stretching, vibrations at 2368 $\mathrm{cm}^{-1}$ presence of $\mathrm{C}-\mathrm{H}, \mathrm{O}-\mathrm{H}$ bending, N-O, Zn-O and $\mathrm{Cu}-\mathrm{O}$. Composites of $\mathrm{Cu}-\mathrm{Al} / \mathrm{BC}$ and $\mathrm{Cu}-\mathrm{Al} / \mathrm{GF}$ had all vibrations of $\mathrm{Cu}-\mathrm{Al} \mathrm{LDH}, \mathrm{BC}$, and $\mathrm{GF}$ as a result of two components were involved in the composites.

Figure 5 showed the thermal analysis of materials. The thermogravimetry of $\mathrm{Cu} / \mathrm{Al} \mathrm{LDH}$ patterns had only an exothermic phase because $\mathrm{Cu} / \mathrm{Al} \mathrm{LDH}$ consists of inorganic components. The exothermic peak of $\mathrm{Cu} / \mathrm{Al} \mathrm{LDH}$ was attributed to the decomposition of water at around $110^{\circ} \mathrm{C}$, decomposition of a layer at around $650{ }^{\circ} \mathrm{C}$, and loss of anions on interlayer at around $200-300{ }^{\circ} \mathrm{C}$. BC had organic content thus endother- 


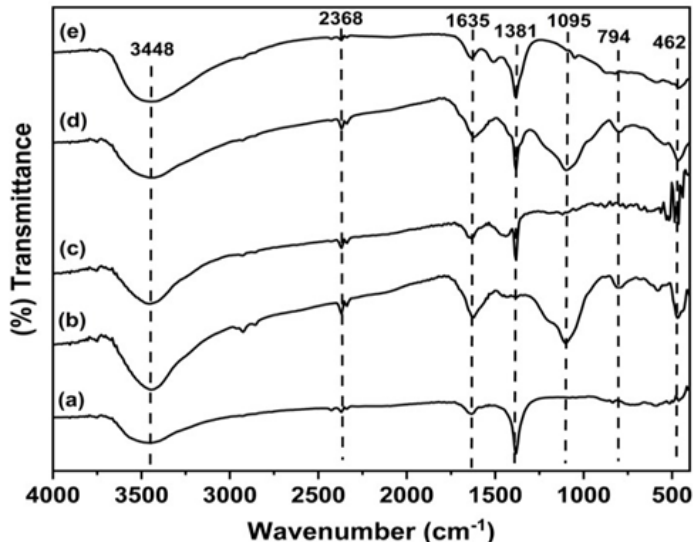

Figure 4. FTIR Spectrum of $\mathrm{Cu} / \mathrm{Al} \mathrm{LDH}$ (a), BC (b), GF (c), $\mathrm{Cu}-\mathrm{Al} / \mathrm{BC}(\mathrm{d})$, and $\mathrm{Cu}-\mathrm{Al} / \mathrm{GF}(\mathrm{e})$

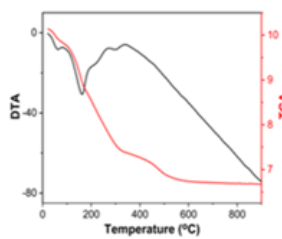

(a)

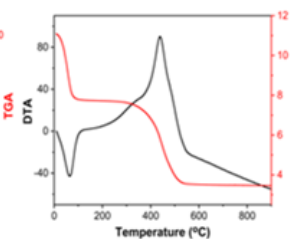

(b)

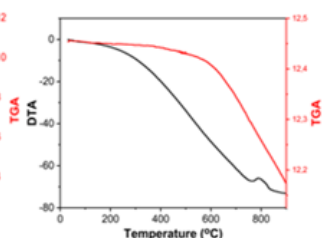

(c)

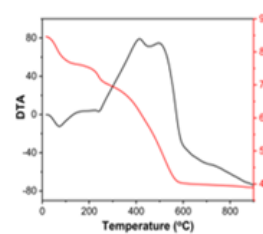

(d)

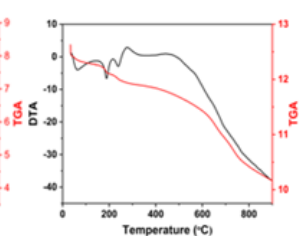

(e)
Figure 5. Thermal Profile of $\mathrm{Cu} / \mathrm{Al} \mathrm{LDH}(\mathrm{a}), \mathrm{BC}(\mathrm{b}), \mathrm{GF}(\mathrm{c})$, $\mathrm{Cu}-\mathrm{Al} / \mathrm{BC}$ (d), and $\mathrm{Cu}-\mathrm{Al} / \mathrm{GF}$ (e)

mic peak was found due to oxidation of organic parts around $490{ }^{\circ} \mathrm{C}$. GF has only one decomposition peak at $760{ }^{\circ} \mathrm{C}$. This decomposition peak was denoted that $\mathrm{GF}$ was pure without other ingredients, including water. $\mathrm{Cu}-\mathrm{Al} / \mathrm{BC}$ and $\mathrm{Cu}-\mathrm{Al} / \mathrm{GF}$ composites had organic and inorganic components thus had two kinds of endothermic and exothermic peaks.

Table 2 shows the adsorption concentration of each dye in the selectivity of anionic dye mixtures. Based on the data in Table 2, the concentration of PR adsorption is greater compared to other dyes. This suggests that PR is more easily to adsorption process using $\mathrm{Cu}-\mathrm{Al} / \mathrm{BC}$ and $\mathrm{Cu}-\mathrm{Al} / \mathrm{GF}$ adsorbents. The results of the regeneration of each adsorbent on the PR dye can be seen in Figure 6. As an equal result of increasing surface area properties after the formation of composite $\mathrm{Cu}$ $\mathrm{Al} / \mathrm{BC}$ thus adsorption of $\mathrm{PR}$ was higher than starting materials. Starting materials of $\mathrm{Cu} / \mathrm{Al} \mathrm{LDH}$ had a less stable structure so modifications of composites based on carbon materials such as $\mathrm{BC}$ and $\mathrm{GF}$ to produce a stable structure that can be reused



Figure 6. Regeneration of Adsorbents
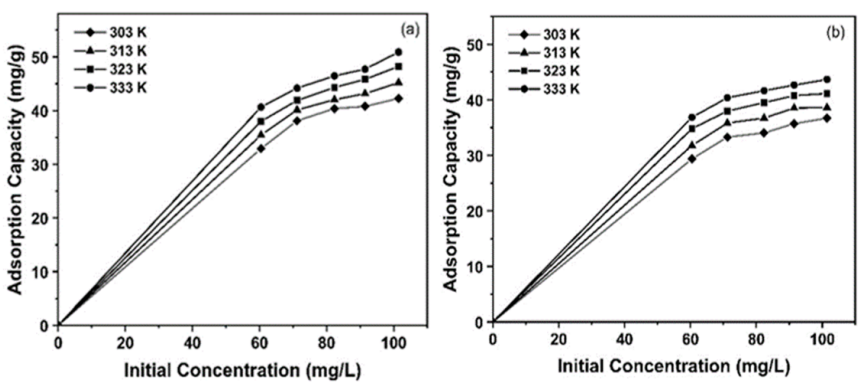

Figure 7. Effect of Initial Concentration of $\mathrm{PR}$ and Adsorption Temperature on $\mathrm{Cu}-\mathrm{Al} / \mathrm{BC}$ (a) and $\mathrm{Cu}-\mathrm{Al} / \mathrm{GF}$ (b)

on the adsorption process. The result of the composites regeneration process on $\mathrm{PR}$ showed that $\mathrm{Cu}-\mathrm{Al} / \mathrm{BC}$ and $\mathrm{Cu}-\mathrm{Al} / \mathrm{GF}$ had structural stability higher than starting materials. Effect of initial concentration of $\mathrm{PR}$ and adsorption temperature on $\mathrm{Cu} / \mathrm{Al}-\mathrm{BC}$ and $\mathrm{Cu}-\mathrm{Al} / \mathrm{GF}$ as shown in Figure 7. Increasing the adsorption temperature will increase the adsorption capacity.

Table 3 presents the isotherm adsorption parameters, which identifies that the Langmuir model is better than the Freundlich model. The Langmuir model indicates the adsorption process is a monolayer. Table 3 showed that the maximum adsorption capacity of $\mathrm{Cu}-\mathrm{Al} / \mathrm{BC}$ is larger than other materials that so it has high effectivity on CR adsorption. Table 4 showed the thermodynamic adsorption of $\mathrm{CR}$. The $\Delta \mathrm{H}$ had positive values indicated that adsorption occurs endothermically which requires an energy of adsorption process. The value of $\Delta \mathrm{G}$ was more negative with increasing temperature indicated that adsorption on all materials was spontaneous. The value of $\Delta \mathrm{S}$ indicated the degree of irregularity. The positive value of $\Delta S$ indicates that an increase in irregularity on the surface. In Table 5, $\mathrm{Cu}-\mathrm{Al} / \mathrm{BC}$ and $\mathrm{Cu}-\mathrm{Al} / \mathrm{GF}$ composites had the highest adsorption capacity than several adsorbents. Thus materials were effective adsorbents to the removal of PR from aqueous solution. 
Table 2. Selectivity of Anionic Dye Mixtures

\begin{tabular}{cccccc}
\hline \multirow{2}{*}{ Adsorbents } & Times & \multicolumn{4}{c}{ Concentration Adsorption $(\mathrm{mg} / \mathrm{L})$} \\
& (Minutes) & MR & MO & PR & CR \\
\hline $\mathrm{Cu}-\mathrm{Al} / \mathrm{BC}$ & 0 & 0.000 & 0.000 & 0.000 & 0.000 \\
& 15 & 0.672 & 0.095 & 1.519 & 0.476 \\
& 30 & 3.507 & 0.587 & 8.228 & 1.349 \\
& 60 & 5.149 & 1.591 & 15.063 & 3.492 \\
& 90 & 5.821 & 2.008 & 25.443 & 5.556 \\
$\mathrm{Cu}-\mathrm{Al} / \mathrm{GF}$ & 120 & 6.791 & 2.140 & 36.203 & 7.619 \\
& 0 & 0.000 & 0.000 & 0.000 & 0.000 \\
& 15 & 0.597 & 0.303 & 0.127 & 0.317 \\
& 30 & 0.896 & 1.420 & 7.848 & 1.190 \\
& 60 & 2.836 & 1.591 & 10.000 & 3.095 \\
& 90 & 4.179 & 1.818 & 11.772 & 3.413 \\
& 120 & 5.746 & 1.837 & 13.418 & 3.651 \\
\hline
\end{tabular}

Table 3. Isotherm Adsorption

\begin{tabular}{ccccccc}
\hline \multirow{2}{*}{ Adsorbents } & $\begin{array}{c}\text { Adsorption } \\
\text { Isotherm }\end{array}$ & $\begin{array}{c}\text { Adsorption } \\
\text { Constant }\end{array}$ & 30 & 40 & 50 & 60 \\
\hline \multirow{2}{*}{$\mathrm{Cu}-\mathrm{Al} / \mathrm{BC}$} & \multirow{2}{*}{ Langmuir } & Qmax & 53.476 & 63.291 & 81.301 & 93.458 \\
& & $\mathrm{~kL}$ & 0.066 & 0.074 & 0.081 & 0.106 \\
& & $\mathrm{R}^{2}$ & 0.984 & 0.995 & 0.998 & 0.995 \\
& \multirow{2}{*}{ Freundlich } & $\mathrm{n}$ & 3.425 & 3.667 & 3.801 & 4.507 \\
& & $\mathrm{kF}$ & 13.107 & 15.160 & 16.939 & 21.023 \\
& & $\mathrm{R}^{2}$ & 0.845 & 0.929 & 0.984 & 0.977 \\
$\mathrm{Cu}-\mathrm{Al} / \mathrm{GF}$ & Langmuir & $\mathrm{Qmax}^{\circ}$ & 46.296 & 46.512 & 47.393 & 49.505 \\
& & $\mathrm{~kL}$ & 0.060 & 0.084 & 0.114 & 0.132 \\
& & $\mathrm{R}^{2}$ & 0.992 & 0.992 & 0.999 & 0.999 \\
& Freundlich & $\mathrm{n}$ & 3.576 & 4.216 & 5.157 & 5.596 \\
& & $\mathrm{kF}^{2}$ & 11.564 & 14.800 & 18.897 & 21.340 \\
& & $\mathrm{R}^{2}$ & 0.911 & 0.871 & 0.941 & 0.936 \\
\hline
\end{tabular}

Table 4. Thermodynamic Adsorption

\begin{tabular}{cccccc}
\hline \multirow{2}{*}{ Adsorbents } & $\mathrm{T}(\mathrm{K})$ & $\mathrm{Qe}(\mathrm{mg} / \mathrm{g})$ & $\begin{array}{c}\Delta \mathrm{H} \\
(\mathrm{kJ} / \mathrm{mol})\end{array}$ & $\begin{array}{c}\Delta \mathrm{S} \\
(\mathrm{J} / \mathrm{mol} . \mathrm{K})\end{array}$ & $\begin{array}{c}\Delta \mathrm{G} \\
(\mathrm{kJ} / \mathrm{mol})\end{array}$ \\
\hline $\mathrm{Cu}-\mathrm{Al} / \mathrm{BC}$ & 303 & 32.911 & 15.041 & 0.051 & -0.423 \\
& 313 & 35.443 & & & -0.934 \\
& 323 & 37.975 & & & -1.444 \\
$\mathrm{Cu}-\mathrm{Al} / \mathrm{GF}$ & 303 & 29.367 & 14.327 & 0.047 & -1.955 \\
& 313 & 31.772 & & & -0.157 \\
& 323 & 34.810 & & & -0.779 \\
& 333 & 36.835 & & & -1.246 \\
\hline
\end{tabular}


Table 5. Adsorption of PR by Several Adsorbents

\begin{tabular}{ccc}
\hline Materials & $\begin{array}{c}\text { Adsorption Capacity } \\
(\mathrm{mg} / \mathrm{g})\end{array}$ & References \\
\hline Corncob Activated Carbon & 2.86 & (Nazifa et al., 2018) \\
Spent Tea Leaves & 3.28 & (Heraldy et al., 2016) \\
Waste Fe (III)/Cr (III) Hydroxide & 3.28 & (Namasivayam and Sumithra, 2006) \\
Agricultural Wastes & 6.12 & (Nor et al., 2015) \\
Raw and Acid-Treated Montmorillonite K10 & 11.04 & (Sarma et al., 2018) \\
Luffa cylindrica & 13.9 & (Oliveira et al., 2011) \\
Cornstalk & 15.9 & (Hu and Hu, 2014) \\
Sewage Sludge Ash (SSA) & 28.82 & This Research \\
Cu-Al/BC & 93.458 & This Research \\
Cu-Al/GF & 49.505 &
\end{tabular}

\section{CONCLUSIONS}

Innovative modification of $\mathrm{Cu}-\mathrm{Al} / \mathrm{BC}$ and $\mathrm{Cu}-\mathrm{Al} / \mathrm{GF}$ composites was successfully formed. The surface area properties of $\mathrm{Cu}-$ $\mathrm{Al} / \mathrm{BC}$ and $\mathrm{Cu}-\mathrm{Al} / \mathrm{GF}$ were larger than starting materials, which obtained $200.90 \mathrm{~m}^{2} / \mathrm{g}$ and $18.83 \mathrm{~m}^{2} / \mathrm{g}$ respectively. Based on the selectivity test for anionic dye mixtures, it is known that $\mathrm{PR}$ is more easily adsorbed than other anionic dyes. $\mathrm{Cu}-\mathrm{Al} / \mathrm{BC}$ and $\mathrm{Cu}-\mathrm{Al} / \mathrm{GF}$ composites were high structural stability on PR re-adsorption process until five cycles process. The maximum adsorption capacity obtained was $93.458 \mathrm{mg} / \mathrm{g}$ for $\mathrm{Cu}-\mathrm{Al} / \mathrm{BC}$ and $49.505 \mathrm{mg} / \mathrm{g}$ for $\mathrm{Cu}-\mathrm{Al} / \mathrm{GF}$. Thus, $\mathrm{Cu}-\mathrm{Al} / \mathrm{BC}$ and $\mathrm{Cu}-$ $\mathrm{Al} / \mathrm{GF}$ can be used as an effective adsorbents to removal of $\mathrm{PR}$ from aqueous solution.

\section{AGKNOWLEDGEMENT}

Authors are acknowledgement to Universitas Sriwijaya through Hibah Profesi 2021 for this financial research by contract No. 0014/UN9/SK.LP2M.PT/2021. Special thanks to Research Center of Inorganic Materials and Complexes FMIPA Universitas Sriwijaya for laboratory analysis.

\section{REFERENCES}

Badri, A. F., P. M. S. B. N. Siregar, N. R. Palapa, R. Mohadi, M. Mardiyanto, and A. Lesbani (2021). Mg-Al/Biochar Composite with Stable Structure for Malachite Green Adsorption from Aqueous Solutions. Bulletin of Chemical Reaction Engineering and Catalysis, 16(1); 149-160

Demissie, H., G. An, R. Jiao, T. Ritigala, S. Lu, and D. Wang (2021). Modification of high content nanocluster-based coagulation for rapid removal of dye from water and the mechanism. Separation and Purification Technology, 259; 117845

Eltaweil, A., H. A. Mohamed, E. M. Abd El-Monaem, and G. El-Subruiti (2020). Mesoporous magnetic biochar composite for enhanced adsorption of malachite green dye: Characterization, adsorption kinetics, thermodynamics and isotherms. Advanced Powder Technology, 31(3); 1253-1263

Heraldy, E., R. R. Osa, and V. Suryanti (2016). Adsorption of Procion Red MX 8B using spent tea leaves as adsorbent. AIP Conference Proceedings, 17 10(1); 30025

Hu, S.-H. and S.-C. Hu (2014). Application of magnetically modified sewage sludge ash (SSA) in ionic dye adsorption. Journal of the Air and Waste Management Association, 64(2); 141-149

Hua, P., L. Sellaoui, D. Franco, M. S. Netto, G. L. Dotto, A. Bajahzar, H. Belmabrouk, A. Bonilla-Petriciolet, and Z. Li (2020). Adsorption of acid green and procion red on a magnetic geopolymer based adsorbent: Experiments, characterization and theoretical treatment. Chemical Engineering Journal, 383; 123113

Juleanti, N., N. R. Palapa, T. Taher, N. Hidayati, B. I. Putri, and A. Lesbani (2021). The Capability of Biochar-Based $\mathrm{CaAl}$ and $\mathrm{MgAl}$ Composite Materials as Adsorbent for Removal Cr(VI) in Aqueous Solution. Science and Technology Indonesia, 6(3); 196-203

Kumar, S. G. and K. K. Rao (2017). Comparison of modification strategies towards enhanced charge carrier separation and photocatalytic degradation activity of metal oxide semiconductors $\left(\mathrm{TiO}_{2}, \mathrm{WO}_{3}\right.$ and $\left.\mathrm{ZnO}\right)$. Applied Surface Science, 391; 124-148

Kusrini, E., A. Suhrowati, A. Usman, M. Khalil, and V. Degirmenci (2019). Synthesis and characterization of graphite oxide, graphene oxide and reduced graphene oxide from graphite waste using modified Hummers's method and zinc as reducing agent. Synthesis, 10(6); 1093-1104

Lellis, B., C. Z. Fávaro-Polonio, J. A. Pamphile, and J. C. Polonio (2019). Effects of textile dyes on health and the environment and bioremediation potential of living organisms. Biotechnology Research and Innovation, 3(2); 275-290

Mcyotto, F., Q. Wei, D. K. Macharia, M. Huang, C. Shen, and C. W. Chow (2021). Effect of dye structure on color removal efficiency by coagulation. Chemical Engineering Journal, 405; 126674

Mohammad, S., I. Suzylawati, et al. (2020). Study of the adsorption/desorption of MB dye solution using bentonite adsorbent coating. Journal of Water Process Engineering, 34; 


\section{5}

Mustapha, S., M. Ndamitso, A. Abdulkareem, J. Tijani, A. Mohammed, and D. Shuaib (2019). Potential of using kaolin as a natural adsorbent for the removal of pollutants from tannery wastewater. Heliyon, 5(11); 2923

Namasivayam, C. and S. Sumithra (2006). Adsorption of anionic dyes on to waste $\mathrm{Fe}$ (III)/Cr (III). Journal of Environmental Science and Engineering, 48(1); 69-74

Natarajan, S., V. Anitha, G. P. Gajula, and V. Thiagarajan (2020). Synthesis and characterization of magnetic superadsorbent $\mathrm{Fe}_{3} \mathrm{O}_{4}$-PEG-Mg-Al-LDH nanocomposites for ultrahigh removal of organic dyes. ACS Omega, 5(7); 31813193

Nazifa, T. H., N. Habba, A. Aris, and T. Hadibarata (2018). Adsorption of Procion Red MX-5B and Crystal Violet Dyes from Aqueous Solution onto Corncob Activated Carbon. Journal of the Chinese Chemical Society, 65(2); 259-270

Nor, N. M., T. Hadibarata, Z. Yusop, and Z. M. Lazim (2015). Removal of brilliant green and procionred dyes from aqueous solutionby adsorption using selected agricultural wastes. Jurnal Teknologi, 74(11); 11

Normah, N. R. Palapa, T. Taher, R. Mohadi, H. P. Utami, and A. Lesbani (2021). The Ability of Composite Ni/Al-carbon based Material Toward Readsorption of Iron(II) in Aqueous Solution. Science and Technology Indonesia, 6(3); 156-165

Oliveira, E., S. Montanher, and M. Rollemberg (2011). Removal of textile dyes by sorption on low-cost sorbents. A case study: sorption of reactive dyes onto Luffa cylindrica. Desalination and Water Treatment, 25(1-3); 54-64

Palapa, N. R., N. Juleanti, N. Normah, T. Taher, and A. Lesbani (2020a). Unique adsorption properties of malachite green on interlayer space of $\mathrm{Cu}-\mathrm{Al}$ and $\mathrm{Cu}-\mathrm{Al}-\mathrm{SiW} 12 \mathrm{O} 40$ layered double hydroxides. Bulletin of Chemical Reaction Engineering and Catalysis, 15(3); 653-661

Palapa, N. R., R. Mohadi, and A. Lesbani (2018). Adsorption of direct yellow dye from aqueous solution by $\mathrm{Ni} / \mathrm{Al}$ and $\mathrm{Zn} / \mathrm{Al}$ layered double hydroxides. AIP Conference Proceedings, 2026(1); 20018

Palapa, N. R., B. R. Rahayu, T. Taher, A. Lesbani, and R. Mohadi (2019). Kinetic Adsorption of Direct Yellow Onto $\mathrm{Zn} / \mathrm{Al}$ and $\mathrm{Zn} / \mathrm{Fe}$ Layered Double Hydroxides. Science and Technology Indonesia, 4(4); 101-104

Palapa, N. R., T. Taher, B. R. Rahayu, R. Mohadi, A. Rachmat, and A. Lesbani (2020b). CuAl LDH/Rice husk biochar composite for enhanced adsorptive removal of cationic dye from aqueous solution. Bulletin of Chemical Reaction Engineering and Catalysis, 15(2); 525-537

Quesada, H. B., T. P. de Araujo, D. T. Vareschini, M. A. S. D. de Barros, R. G. Gomes, and R. Bergamasco (2020). Chi- tosan, alginate and other macromolecules as activated carbon immobilizing agents: a review on composite adsorbents for the removal of water contaminants. International Journal of Biological Macromolecules, 164; 2535-2549

Sarkar, S., A. Banerjee, U. Halder, R. Biswas, and R. Bandopadhyay (2017). Degradation of synthetic azo dyes of textile industry: a sustainable approach using microbial enzymes. Water Conservation Science and Engineering, 2(4); $121-131$

Sarma, G. K., S. SenGupta, and K. G. Bhattacharyya (2018). Adsorption of monoazo dyes (Crocein Orange $G$ and Procion Red MX5B) from water using raw and acid-treated montmorillonite K10: insight into kinetics, isotherm, and thermodynamic parameters. Water, Air, and Soil Pollution, 229(10); 1-17

Shi, Q.-X., Y. Li, L. Wang, J. Wang, and Y.-L. Cao (2020). Preparation of supported chitosan adsorbent with high adsorption capacity for Titan Yellow removal. International Journal of Biological Macromolecules, 152; 449-455

Siregar, P. M. S. B. N., N. R. Palapa, A. Wijaya, E. S. Fitri, and A. Lesbani (2021). Structural stability of Ni/Al layered double hydroxide supported on graphite and biochar toward adsorption of congo red. Science and Technology Indonesia, 6(2); 85-95

Streit, A. F., L. N. Côrtes, S. P. Druzian, M. Godinho, G. C. Collazzo, D. Perondi, and G. L. Dotto (2019). Development of high quality activated carbon from biological sludge and its application for dyes removal from aqueous solutions. Science of The Total Environment, 660; 277-287

Tang, R., Y. Wang, S. Yuan, W. Wang, Z. Yue, X. Zhan, and Z.-H. Hu (2020). Organoarsenic feed additives in biological wastewater treatment processes: Removal, biotransformation, and associated impacts. Journal of Hazardous Materials; 124789

Valencia, S., M. Pascua, J. Movillon, and H. Braza (2001). Adsorption of basic rhodamine red, basic methylene blue, reactive procion red, and reactive procion blue textile dyes by cornstalk. Philippine Agricultural Scientist (Philippines), 84(3); 304-312

Zhang, M., Q. Yao, C. Lu, Z. Li, and W. Wang (2014). Layered double hydroxide-carbon dot composite: high-performance adsorbent for removal of anionic organic dye. ACS Applied Materials and Interfaces, 6(22); 20225-20233

Zhao, J., Q. Huang, M. Liu, Y. Dai, J. Chen, H. Huang, Y. Wen, X. Zhu, X. Zhang, and Y. Wei (2017). Synthesis of functionalized MgAl-layered double hydroxides via modified mussel inspired chemistry and their application in organic dye adsorption. Journal of Colloid and Interface Science, 505; $168-177$ 